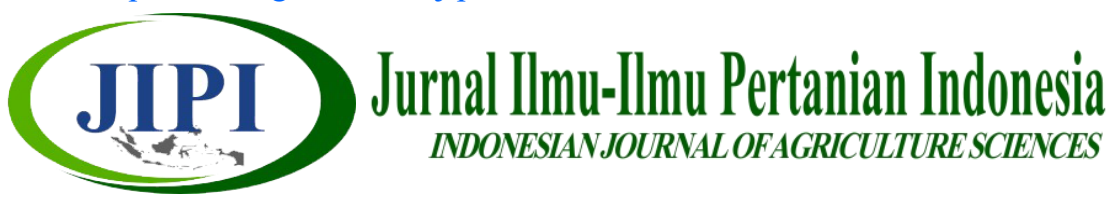

\title{
TINGKAT SERANGAN HAMA PENGGEREK POLONG, Maruca testulalis Geyer (Lepidoptera: Pyralidae)) PADA DELAPAN VARIETAS KACANG HIJAU (Vigna radiata L.) DAN PENGARUHNYA TERHADAP HASIL
}

\author{
Minal Faizin ${ }^{1}$, Nadrawati $^{2}$, Edhi Turmudi ${ }^{1 *}$ \\ ${ }^{1}$ Program Studi Agroekoteknologi, Fakultas Pertanian Universitas Bengkulu \\ ${ }^{1}$ Program Studi Proteksi Tanaman, Fakultas Pertanian Universitas Bengkulu \\ * Corresponding Author :turmudi@unib.ac.id
}

\begin{abstract}
[THE INCIDENCE OF POD-BORER, Maruca testulalis Geyer (Lepidoptera: Pyralidae) IN EIGHT MUNG BEAN VARIETIES (Vigna radiata L.) AND ITS EFFECT ON YIELD]. Mung beans are an essential food crop in Indonesia, whose production is still increasing to meet domestic needs. However, the high attack of plant pests Maruca testulalis Geyer (Lepidoptera: Pyralidae) is one of the leading causes of the low production of green beans. The use of superior varieties is one solution to controlling these pests. This study was conducted to test seven superior varieties of green beans, namely Vima 1, Vima 2, Vima 3, Murai, Kenari, Kutilang and Seriti and one local variety against $M$. testulalis. The study used a completely randomized block design and was repeated three times. The results showed that the mungbean varieties Vima 1, Vima 2, and Vima 3 had M. testulalis attack with the lowest level of seed damage in sequence, namely $5.84 \%, 7.94 \%$, and $6.39 \%$. Even though the percentage of pod borers attack did not significantly affect the growth of all Balitkabi superior varieties and one local variety of mungbean planted, the Kutilang variety was the highest yield with seed yield rates that were as low as other low-attack varieties.
\end{abstract}

Keyword: Maruca testulalis, mung bean varieties

\begin{abstract}
ABSTRAK
Kacang hijau adalah tanaman pangan penting di Indonesia yang peningkatan produksinya masih terus dilakukan untuk memenuhi kebutuhan domestik. Akan tetapi, tingginya serangan hama tanaman Maruca testulalis Geyer (Lepidoptera: Pyralidae) menjadi salah satu penyebab utama rendahnya produksi kacang hijau. Penggunaan varietas unggul merupakan salah satu solusi untuk mengendalikan hama tersebut. Penelitian ini dilakukan untuk menguji tujuh varietas unggul kacang hijau yaitu Vima 1, Vima 2, Vima 3, Murai, Kenari, Kutilang, Seriti dan satu varietas lokal terhadap serangan $M$. testulalis. Penelitian menggunakan rancangan acak kelompok lengkap dan diulang tiga kali. Hasil penelitian menunjukkan bahwa kacang hijau varietas Vima 1, Vima 2 dan Vima 3 mengalami serangan $M$. testulalis dengan tingkat kerusakan biji paling rendah secara berurutan yaitu 5,84\%, 7,94\% dan 6,39\%. Meskipun persentase serangan hama penggerek polong tidak berpengaruh nyata terhadap pertumbuhan seluruh varietas unggul Balitkabi dan satu varietas lokal kacang hijau yang ditanam, varietas Kutilang merupakan varietas dengan hasil produksi biji yang tertinggi dengan tingkat kerusakan biji yang sama rendahnya dengan varietas yang mengalami serangan terendah lainnya.
\end{abstract}

Kata kunci: Maruca testulalis, varietas, kacang hijau, hama tanaman 


\section{PENDAHULUAN}

Kacang hijau (Vigna radiata L.) adalah salah satu tanaman pangan jenis kacang-kacangan yang sudah dikenal luas oleh masyarakat Indonesia. Nilai gizi yang terkandung dalam kacang hijau sangat beragam yaitu protein, vitamin (A, B, C dan E), karbohidrat dan mineral (Purwono \& Hartono, 2005). Produk olahan kacang hijau tidak hanya berbentuk tepung, namun juga dapat berupa tahu, tempe, susu dan olahan kering lainnya (Iswandari, 2006 ; Komah, 2013 ; Ekafitri \& Isworo, 2014 ; Andrestian \& Hatimah, 2015).

Produksi kacang hijau di Provinsi Bengkulu terus mengalami penurunan selama beberapa tahun terakhir. Tercatat pada tahun 2013 produksi kacang hijau sebesar 1.371 ton, namun pada tahun 2014 dan 2015 menurun berurutan menjadi 1.154 ton dan 662 ton. Menurunnya produksi kacang hijau tersebut disebabkan oleh berkurangnya jumlah luasan lahan dan kemampuan produktivitas tanaman itu sendiri (BPS, 2017). Oleh sebab itu perlu dilakukan upaya pengembangan untuk meningkatkan produktivitas kacang hijau yang sudah ada agar hasilnya meningkat sehingga kebutuhan konsumsi dapat terpenuhi tanpa harus mengimpor.

Salah satu masalah yang dihadapi dalam pengembangan budidaya kacang hijau adalah serangan hama. Menurut Marwoto (1993), kehilangan hasil akibat serangan hama pada tanaman kacang hijau dapat mencapai $60 \%$, bahkan jika serangan berat tanaman tidak menghasilkan sama sekali. Tanaman kacang hijau diketahui berasosiasi dengan 85 spesies hama dan lebih dari 20 jenis hama tersebut telah diketahui ada di Indonesia. Penelitian Nugraha (2013), mencatat jenis hama pada tanaman kacang hijau di Kelurahan Situgede, Kecamatan Bogor Barat, Bogor, Jawa Barat antara lain yaitu Ophiomya phaseoli Aphis craccivora, Empoasca spp., dan Thrips spp., Riptortus linearis, Nezara viridula, dan Maruca testulalis.

Penggerek polong $M$. testulalis adalah hama penting mempunyai distribusi yang sangat luas di berbagai benua Afrika, Asia dan Amerika. Tanaman inang $M$. testulalis antara lain tanaman kacang panjang, kacang kedelai, kacang hijau, krotalaria dan jenis kacang-kacang lainnya. Di Indonesia penggerek polong tersebar luas di Jawa dan Sumatera terutama di daerah penghasil kacang panjang dan kacang hijau (Pitojo, 2006; Singh et al., 2008). Tanda serangan hama $M$. testulalis pada tanaman kacang panjang terdapat pada tunas, bunga, daun muda dan polong muda, juga terkadang larva memakan bagian daun dan batang tanaman yang lembut (Saragih \& Pangestiningsih, 2015; Kalshoven, 1981).

Seranganb $M$. testulalis pada tanaman kacang hijau tidak hanya pada polong, tetapi juga pada tunas muda, kuncup muda, bunga dan daun (Talekar, 1998). Pengendalian hama ini sangat penting dilakukan sebab dapat mengakibatkan kehilangan hasil antara 13-59 \% (Indiati, 2007).
Selama ini sebagian besar petani mengendalikan hama penggerek polong menggunakan insektisida sintetik. Mengingat penggunaan bahan kimia sintetik memiliki dampak negatif terhadap lingkungan dan keberlanjutan kegiatan produksi, maka diperlukan altenatif lain seperti penggunaan varietas unggul yang tahan dan atau toleran.

Varietas unggul merupakan komponen teknologi produksi yang murah, mudah diadopsi petani serta aman terhadap kelestarian lingkungan. Beberapa varietas kacang hijau yang telah dilepas oleh Balitkabi adalah Vima 1, Vima 2, Vima 3, Murai, Kenari, Sriti dan Kutilang (Balitkabi, 2012). Beberapa varietas yang tersedia tersebut belum pernah dilakukan penelitian tentang responnya terhadap hama penggerek dan penghisap polong di Bengkulu dan belum ada varietas yang dilepas ke petani sebagai varietas yang tahan terhadap serangan hama penggerek polong. Guna memperkaya keberagaman varietas di Bengkulu, maka diperlukan introduksi varietas untuk dikaji adaptabilitasnya terhadap hama penggerek dan penghisap polong. Informasi yang diperoleh akanberguna sebagai dasar pengelolaan hama dan pemilihan jenis varietas guna peningkatan produksi tanaman kacang hijau.Tujuan dari penelitian ini adalah untuk mengetahui tingkat kerusakan delapan varietas kacang hijau terhadap serangan hama penggerek polong (M. testulalis) dan pengaruhnya terhadap hasil.

\section{METODE PENELITIAN}

Penelitian dilakakukan pada bulan Maret-Mei 2018 di lahan pertanian milik warga Desa Sri Katon, Kecamatan Pondok Kelapa, Kabupaten Bengkulu Tengah, Provinsi Bengkulu. Percobaan ini menggunakan Rancangan Acak Kelompok Lengkap (RAKL) dengan delapan varietas diperoleh dari Balitkabi (Vima 1, Vima 2, Vima 3, Murai, Kenari, Kutilang dan Sriti) dan satu varietas lokal, yang masing-masing diulang sebanyak 3 kali, sehingga terdapat 24 unit percobaan. Tanaman sampel untuk pengamatan variabel agronomi dan variabel serangan hama ditentukan secara acak sebanyak 16\%/petak dengan mengabaikan tanaman pinggir.

Penelitian ini dilaksanakan dalam beberapa tahapan yaitu persiapan lahan, penanaman, pemeliharaan dan pemanenan. Persiapan lahan dilakukan dengan cara membersihkan lahan dari gulma dan sisa-sisa tanaman yang ada dengan menggunakan parang dan sabit. Tanah dicangkul sampai gembur dan diratakan lalu dibuat petakan dengan ukuran $200 \mathrm{~cm}$ x $200 \mathrm{~cm}$, tinggi $10 \mathrm{~cm}$ dengan jarak antar petakan $50 \mathrm{~cm}$ dan jarak antar blok $200 \mathrm{~cm}$, dengan jarak tanam $40 \mathrm{~cm} x$ $20 \mathrm{~cm}$ sehingga setiap unit percobaan berisi 50 tanaman dan 8 tanaman dijadikan sampel. Penanaman dilakukan dengan sistem tugal dengan kedalaman 3 $5 \mathrm{~cm}$, setiap lubang tanam diberi 2-3 benih kacang 
hijau. Untuk mencegah serangan hama dan penyakit pada biji dan kecambah, pada saat tanam diberikan Karbofuran $3 \%$ ) sebanyak 3 - 5 butir/ lubang tanam.

Pemeliharaan tanaman yang dilakukan adalah penyulaman, penyiangan, penjarangan, pembumbunan, penyiraman, dan pemupukan. Penyulaman dilakukan satu minggu setelah tanam (mst), dengan cara menanam kembali benih pada lubang tanam yang tanamannya mati atau pertumbuhannya tidak normal saat berumur 1 mst. Penyiangan dilakukan pada 2 mst dan 5 mst . Penjarangan dilakukan pada saat tanaman berusia 2 mst, untuk pembubunan dilakukan pada saat penyiangan ke-1 dan ke-3. Pupuk yang diberikan berupa Urea dengan dosis $45 \mathrm{~kg} / \mathrm{ha}$, TSP $45 \mathrm{~kg} / \mathrm{ha}$, dan $\mathrm{KCl} 50 \mathrm{~kg} / \mathrm{ha}$. Semua pupuk diberikan saat tanam dengan cara ditugal di samping lubang tanam. Urea diberikan dalam dua tahap yaitu $22,5 \mathrm{~kg} / \mathrm{ha}$ pada saat penanaman dan $22,5 \mathrm{~kg} / \mathrm{ha}$ pada saat tanaman telah berumur 2 mst.

Kacang hijau dipanen pada umur 56 - 67 hari, dengan kriteria panen yaitu berubahnya warna polong dari hijau menjadi hitam atau coklat dan kering. Panen dilakukan dengan cara dipetik. Polong yang sudah dipanen lalu dijemur, hingga polong terlihat mulai pecah lalu dimasukkan dalam kantong plastik ukuran $60 \mathrm{~cm}$ x $70 \mathrm{~cm}$ lalu diinjak - injak sehingga biji terpisah dengan polong. Biji yang sudah bersih dijemur kembali untuk menurunkan kadar air hingga berat polong konstan.

Variabel yang diamati terdiri dari, tinggi tanaman, kepadatan trikoma, jumlah polong/tanaman, jumlah polong terserang/tanaman, persentase kerusakan polong, jumlah biji/tanaman, persentase kerusakan biji/polong, persentase kerusakan biji/ tanaman, bobot biji kering/tanaman, bobot biji kering/petak, dan bobot 100 biji kering.

Data yang diperoleh dianalisis menggunakan analisis varian (ANAVA) pada taraf 5\%. Variabel yang berbeda nyata antar perlakuan dilanjutkan dengan uji Beda Nyata Terkecil (BNT). Untuk menentukan keterkaitan serangan hama dan hasil kacang hijau dilakukan dengan analisis korelasi (Sarwono, 2006).

\section{HASIL DAN PEMBAHASAN}

Hasil analisis varian menunjukkan pengaruh nyata $(\mathrm{P} \leq 0,05)$ pada variabel tinggi tanaman, kepadatan trikoma, bobot 100 biji, bobot biji/petak, dan persentase kerusakan biji/polong. Varietas Vima 3 adalah varietas dengan nilai rerata tinggi tanaman tertinggi, yakni $79 \mathrm{~cm}$ sedangkan varietas Vima 1 terendah, yakni $59,23 \mathrm{~cm}$. Adanya perbedaan tinggi tanaman antar delapan varietas kacang hijau tersebut kemungkinan disebabkan oleh faktor genetik, karena lokasi penelitian memiliki tingkat kesuburan relatif sama (Sitompul \& Guritno, 1995).
Secara umum semua varietas memiliki pertumbuhan yang baik jika dilihat dari tinggi tanaman (Tabel 1). Pada beberapa varietas yang diuji cenderung memiliki tinggi tanaman yang lebih tinggi dibandingkan dengan potensi yang dijelaskan pada deskripsi varietas yang dikeluarkan oleh Balitkabi. Khususnya varietas Kutilang yang merupakan varietas dengan kemampuan adaptasi terhadap lingkungan yang terbaik dibandingkan varietas lain. Hal ini dibuktikan dengan tinggi tanaman pada varietas tersebut mencapai 18\% lebih tinggi dari potensi optimal dalam deskripsi varietas yang telah ada. Varietas Vima 3 memiliki tinggi tanaman hanya $4 \%$ lebih tinggi dari potensinya. Perbedaan tinggi tanaman dapat disebabkan daya adaptasi yang berbeda-beda setiap varietas (Rahayu \& Sumpena, 2015).

Pertumbuhan yang baik dari varietas Kutilang berpengaruh positif terhadap hasil yang didapatkan, tergambar dari nilai rata-rata bobot/petak tertinggi (Tabel 1). Organ vegetatif, salah satunya tinggi tanaman memiliki hubungan yang erat terhadap produksi (Surtinah, 2007). Selain itu, varietas Kutilang dengan kemampuan adaptasinya terhadap lingkungan juga berdampak pada bobot 100 biji tertinggi. Faktor interaksi genetik dengan lingkungan atau adaptasi memiliki peran penting dalam menentukan potensi hasil biji kacang hijau (Yuliati, 2016).

Varietas Kutilang memiliki hasil yang jauh melampaui hasil rata-rata bahkan potensi tertinggi dari hasil deskripsi Balitkabi. Selain itu varietas Kenari dan Vima 1 juga memiliki hasil yang melebihi potensi tertinggi dari deskripsi yang telah ada. Perbedaan hasil ini disebabkan oleh interaksi antara faktor genetik dan lingkungan dan tidak bersifat tetap. Potensi hasil galur kacang hijau bergantung pada kondisi lingkungan/lokasi dan jenis galur yang ditanam sehingga galur kacang hijau yang tumbuh baik pada suatu lokasi belum tentu baik bila ditanam pada lokasi lain, atau peringkat keunggulan varietas berubah dari lokasi ke lokasi (Trustina \& Iswanto (2013). Selain pengaruh faktor interaksi genetik tanaman dan lingkungan abiotik, bobot/petak yang diperoleh pada percobaan ini juga dipengaruhi oleh adanya serangan hama.

Pertumbuhan morfologis tertentu pada tanaman mampu menjadi alat pertahanan terhadap serangan organisme pengganggu. Ketahanan tanaman yang ditentukan oleh struktur tanaman atau karakter morfologi karena gerakan atau aktivitas makan atau perkembangbiakan serangga terganggu serta menghambat peneluran. Adapun sifat tersebut salah satunya dapat disebabkan adanya trikoma pada permukaan tanaman (Howe \& Westly, 1988). Kepadatan trikoma dapat berbeda tergantung oleh varietas kacang hijau. Varietas Murai memiliki kepadatan trikoma paling rapat dengan nilai 126,2 trikoma/cm yang berbeda nyata dengan Sriti, Vima 2, Vima 1, Kenari, Vima 3, Lokal dan Kutilang. 
Tabel 1. Rata-rata pertumbuhan dan hasil delapan varietas kacang hijau (Vigna radiata L.) yang terserang hama penggerek polong Maruca testulalis Geyer (Lepidoptera: Pyralidae)

\begin{tabular}{lccccc}
\hline Varietas & $\begin{array}{c}\text { TT } \\
(\mathrm{cm})\end{array}$ & KT & PKBP & $\begin{array}{c}\text { BBP } \\
(\mathrm{g})\end{array}$ & $\begin{array}{c}\text { B100B } \\
(\mathrm{g})\end{array}$ \\
\hline Kutilang & $71,56 \mathrm{~b}$ & $81,0 \mathrm{e}$ & $11,93 \mathrm{ab}$ & $1014,53 \mathrm{a}$ & $7,01 \mathrm{a}$ \\
Murai & & & & & \\
Murai & $71,59 \mathrm{~b}$ & $126,2 \mathrm{a}$ & $14,08 \mathrm{ab}$ & $605,34 \mathrm{c}$ & $6,16 \mathrm{c}$ \\
Lokal & $60,73 \mathrm{ef}$ & $85,8 \mathrm{e}$ & $10,81 \mathrm{a}$ & $515,60 \mathrm{~d}$ & $5,53 \mathrm{f}$ \\
Sriti & $64,71 \mathrm{~cd}$ & $107,5 \mathrm{~b}$ & $7,58 \mathrm{~b}$ & $702,24 \mathrm{c}$ & $6,00 \mathrm{~d}$ \\
Kenari & $63,14 \mathrm{~d}$ & $95,7 \mathrm{~d}$ & $18,24 \mathrm{a}$ & $836,02 \mathrm{ab}$ & $6,80 \mathrm{~b}$ \\
Vima 1 & $59,23 \mathrm{e}$ & $94,7 \mathrm{~d}$ & $7,99 \mathrm{~b}$ & $784,25 \mathrm{bc}$ & $5,85 \mathrm{e}$ \\
Vima 2 & $67,33 \mathrm{c}$ & $103,3 \mathrm{c}$ & $8,97 \mathrm{~b}$ & $548,69 \mathrm{c}$ & $5,63 \mathrm{f}$ \\
Vima 3 & $79,00 \mathrm{a}$ & $94,0 \mathrm{~d}$ & $8,49 \mathrm{~b}$ & $660,79 \mathrm{c}$ & $6,24 \mathrm{c}$ \\
\hline
\end{tabular}

Keterangan: 1). Angka-angka pada kolom yang sama yang diikuti huruf yang sama berbeda tidak nyata pada uji BNT 5\%. 2).. (TT) Tinggi Tanaman, (KT) Kepadatan Trikoma, (PKBP) Persentase Kerusakan Biji/Polong, (BPP) Bobot Biji/Petak, (B100B) Bobot 100 Biji

Penelitian Tamang et al. (2017) tentang skrining varietas kacang hijau tahan/toleransi serangan serangga hama menghasilkan kesimpulan bahwa tingkat serangan hama dipengaruhi oleh kepadatan trikoma pada permukaan tanaman. Bayu et al. (2015) juga menyatakan bahwa kepadatan trikoma polong menjadi salah satu faktor ketahanan terhadap penggerek polong baik imago maupun larva pada tanaman kedelai. Akan tetapi pada penelitian ini menunjukan kepadatan trikoma tidak memberikan dampak yang nyata pada kerusakan dan bobot polong yang diperoleh. Hal ini terlihat dari adanya perbedaan yang tidak signifikan pada variabel kerusakan polong.

Kepadatan trikoma pada kacang hijau belum bisa diharapkan untuk menjadi pelindung dari serangan penggerek polong $M$. testulalis karena hama tersebut memiliki ukuran tubuh yang relatif besar pada fase larva. Sementara itu Roslim et al. (2015) menyatakan bahwa keberadaan trikoma pada semua bagian tanaman termasuk polong dapat menyulitkan petani dalam kegiatan panen. Walaupun demikian keberadaan trikoma pada bagian tertentu pada tanaman kacang hijau tetap diperlukan, seperti pada daun. Indiati (2004) dalam penelitiannya menyebutkan bahwa rapat dan panjangnya trikoma pada daun kacang hijau galur MLG-716 dapat mengurangi serangan hama trips.

Persentase kerusakan biji per polong yang paling rendah berurutan adalah varietas Sriti $(7,58$ $\%)$, Vima $1(7,99 \%)$, Vima $3(8,49 \%)$, dan Vima
$2(8,97 \%)$. Lebih rendahnya kerusakan biji/ polong pada varietas Vima 1, Vima 3 dan Vima 2, kemungkinan besar karena umur umur panennya yang cepat yaitu 56-60 hst, sedangkan varietas lainya lebih dari $60 \mathrm{hst}$ (Balitkabi, 2012) sehingga waktu serang hama $M$. testulalis lebih singkat dibandingkan dengan varietas lainnya. Berbeda dengan ketiga varietas tersebut, Sriti memiliki umur panen yang lebih panjang yaitu65 hari (Balitkabi, 2012). Rendahnya persentase kerusakan biji pada varietas Sriti diduga adanya peran genetik lain, seperti adanya kandungan senyawa kimia yang membuat hama kurang menyukai bagian tanaman yang menjadi makanannya. Hal tersebut dijelaskan oleh Sodic (2009) bahwa tanaman yang memiliki senyawa kimia yang bersifat sebagai zat penolak terhadap serangga. Selain itu, letak polong pada varietas sriti berada di atas mahkota daun dan menyebabkan $M$. testulalis yang berada pada daun sulit mencapai polong sehingga kerusakan biji menjadi berkurang. Kedua faktor di atas diperkuat oleh Souza et al. (2012) yang meneliti tingkat serangan hama Spodoptera eridania pada beberapa genotip kacang kedelai dan mendapatkan satu genotip yang resisten yang dipengaruhi oleh faktor morfologi dan kimia tanaman sehingga daya konsumsi larva $S$. eridania rendah.

Hasil analisis varian terhadap delapan varietas kacang hijau menunjukkan perbedaan yang tidak nyata terhadap jumlah polong/ tanaman, jumlah polong terserang/ tanaman, persentase kerusakan polong/ tanaman, bobot biji/ tanaman, jumlah biji/ tanaman, dan persentase kerusakan biji/ tanaman. Delapan varietas yang diuji coba pada penelitian ini memiliki tingkat serangan polong oleh hama $M$. testulalis per tanaman berbeda tidak nyata secara statistik, yaitu berkisar antara 35 polong (Gambar 1). Hal tersebut menggambarkan bahwa belum ada mekanisme ketahanan dari tanaman kacang hijau yang dapat menghambat serangan $M$. testulalis. Mekanisme pertahanan yang sangat mungkin pada kacang hijau untuk mengahambat serangan hama tersebut adalah antixenosis, yaitu mengandalkan bentuk morfologi yang kurang disukai oleh hama dalam hal ini adalah trikoma. Hare \& Elle (2002) menyatakan bahwa kerusakan tanaman akibat serangga akan lebih rendah dengan meningkatnya kerapatan trikoma. Akan tetapi, pernyataan tersebut tidak berlaku untuk tanaman kacang hijau, karena trikoma hanya mampu menahan serangan hama yang alat mulutnya mencucuk dan menghisap (Indiati, 2004).

Respon yang sama dari delapan varietas kacang hijau terhadap serangan hama $M$. testulalis adalah persentase kerusakan polong/tanaman yang relatif sama yaitu $14 \%$ hingga $25 \%$ (Gambar 2). Sementara itu persentase kerusakan polong/tanaman dan jumlah polong/tanaman dari delapan varietas kacang hijau yang ditanam juga berbeda tidak nyata secara statistik (Gambar 3). Jumlah polong/tanaman yang relatif 
sama tersebut merupakan dampak pengaruh dari faktor genetik masing-masing varietas kacang hijau yang ditanam.

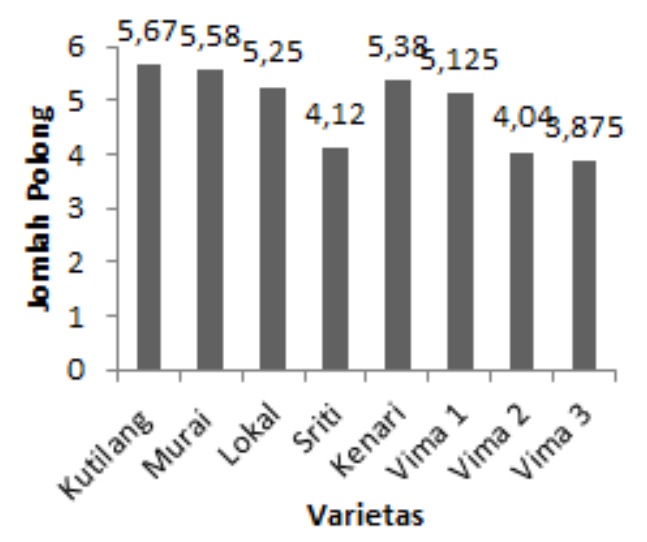

Gambar 1. Jumlah polong terserang/tanaman

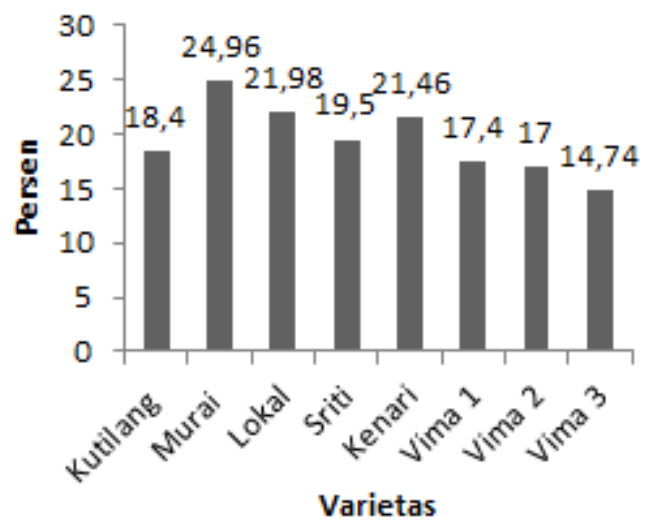

Gambar 2. Persentase kerusakan polong/tanaman

Selain tiga komponen polong di atas, ada tiga variabel dari komponen biji yang juga berbeda tidak nyata secara statistik. Tiga komponen tersebut adalah bobot biji/tanaman, jumlah biji/ tanaman, dan persentase kerusakan biji/tanaman. Bobot biji per tanaman kacang hijau yang cenderung sama yaitu berkisar antara 11,67 g hingga 20,2 g (Gambar 4). Hal tersebut disebabkan oleh jumlah biji per tanaman yang juga relatif sama atau tidak berbeda secara statistik. Perbedaan yang nyata pada bobot 100 biji kacang hijau belum begitu berpengaruh pada bobot/ tanaman. Hal ini diduga karena jumlah biji kacang hijau/tanaman yang sedikit, yaitu berkisar antara 181 hingga 293 biji (Gambar 4). Bobot biji/tanaman per petak juga berbeda secara statistik. Hal itu karena jumlah biji yang ditimbang dalam satuan petakan sudah sangat banyak sehingga bobot 100 biji sudah terlihat pengaruhnya, varietas Kutilang secara konsisten menjadi varietas terbaik pada bobot 100 biji dan bobot biji/petak.

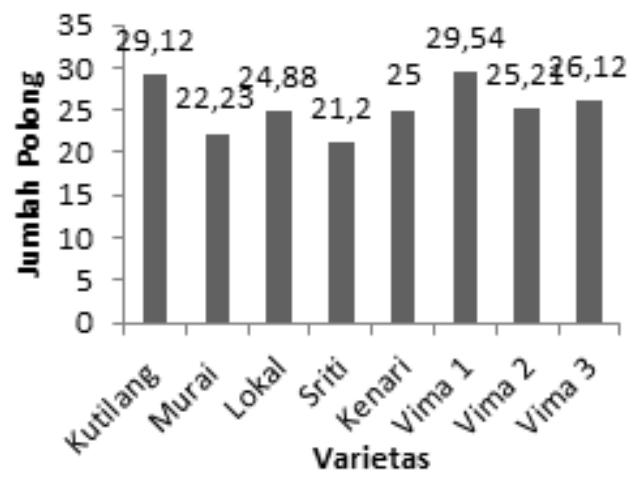

Gambar 3. Jumlah polong/tanaman

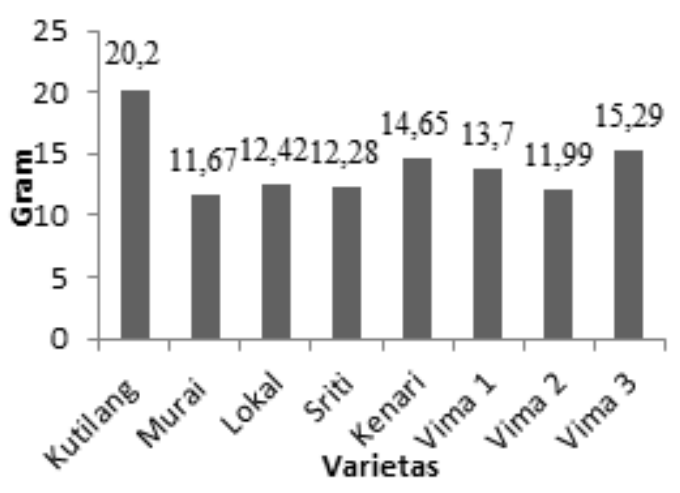

Gambar 4. Bobot biji/tanaman

Persentase kerusakan biji/tanaman secara statistik berbeda tidak nyata dari delapan varietas yang ditanam yaitu berkisar 5,86\%-13,73\% (Gambar 6). Respon yang sama dari delapan varietas kacang hijau terhadap serangan hama penggerek polong $M$. testulalis menggambarkan bahwa belum ada mekanisme pertahanan terhadap serangan hama yang kuat. Selain ituserangan dari hama penggerek polong $M$. testulalis diduga juga merata pada setiap varietas. Hal tersebut dapat dilihat dari jumlah biji yang dihasilkan per tanaman juga berbeda tidak nyata secara statistik dari delapan varietas yang digunakan pada penelitian ini, dengan serangan yang merata tentu saja persentase kerusakan biji/tanaman menjadi tidak nyata.

Koefisien korelasi antara tingkat serangan hama $M$. testulalis dan variabel hasil yang diamati terlihat pada Tabel 2.. Korelasi antara serangan hama $M$. testulalis dengan variabel hasil kacang hijau berkisar 
antara sangat lemah hingga cukup kuat $(0,05<\mathrm{r}<$ $0,27)$. Korelasi antara persentase kerusakan biji/polong dan bobot/petak saja pada bagian ini yang keeratannya cukup kuat $(r=0,274)$. Sedangkan korelasi serangan hama dengan hasil yang lain sangat lemah bahkan hampir tidak berhubungan seperti pada persentase kerusakan biji/tanaman dengan bobot/tanaman dan bobot/petak $(r=-0,05$ dan 0,07$)$. Selain keeratannya yang rendah, korelasi antara serangan hama $M$. testulalis juga tidak signifikan. Hasil uji korelasi tersebut menunjukkan bahwa serangan hama $M$. testulalis tidak mempengaruhi hasil dari kacang hijau yang ditanam di lokasi percobaan.

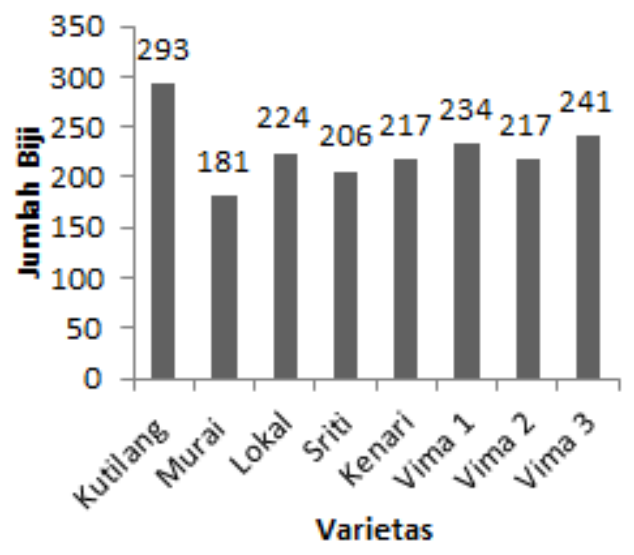

Gambar 5. Jumlah biji/tanaman

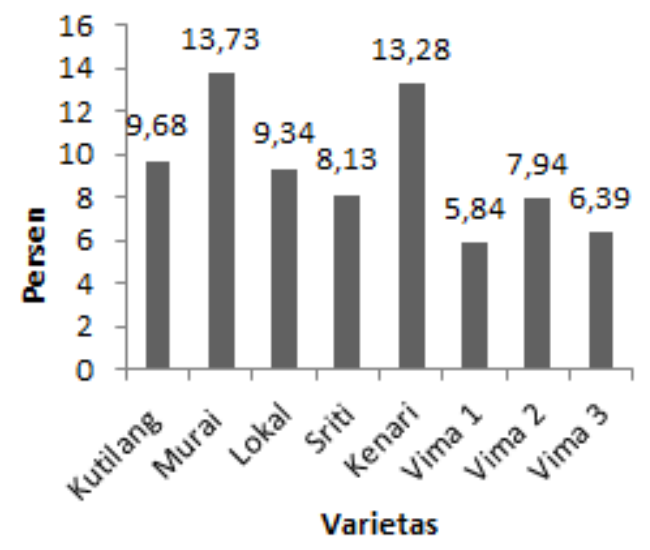

Gambar 6. Persentase kerusakan biji/tanaman
Tabel 2. Korelasi serangan hama penggerek polong, Maruca testulalis Geyer (Lepidoptera: Pyralidae) terhadap hasil kacang hijau (Vigna radiata L.)

\begin{tabular}{cccccc}
\hline Variabel & BPT & BBP & PKBP & PKBT & PKP \\
\hline BPT & 1 & $0,85 * *$ & $\begin{array}{c}0,155 \\
\text { ns }\end{array}$ & $-0,05 \mathrm{~ns}$ & $\begin{array}{c}-0,352 \\
\text { ns }\end{array}$ \\
BBP & & 1 & $\begin{array}{c}0,274 \\
\mathrm{~ns}\end{array}$ & $0,07 \mathrm{~ns}$ & $\begin{array}{c}-0,174 \\
\mathrm{~ns}\end{array}$ \\
PKBP & & 1 & $0,90 * *$ & $0,634 \mathrm{~ns}$ \\
PKBPT & & & & 1 & $0,847 * *$ \\
PKP & & & & & \\
\hline
\end{tabular}

\section{KESIMPULAN}

Tiga varietas dengan kerusakan biji paling rendah akibat serangan penggerek polong, $M$. testulalis adalah Vima 1 (5,84\%), Vima $2(7,94 \%)$ dan Vima 3 $(6,39 \%)$ dibandingkan dengan varietas lainnya. Persentase serangan hama penggerek polong berpengaruh tidak nyata terhadap pertumbuhan dan hasil dari tujuh varietas unggul Balitkabi dan satu varietas lokal kacang hijau. Varietas Kutilang merupakan varietas dengan hasil produksi biji yang tertinggi dengan tingkat kerusakan tergolong rendah.

\section{DAFTAR PUSTAKA}

Andestrian, M. D. \& Hatimah, H. (2015). Daya simpan susu kacang hijau (Phaseolus radiatus L.) dengan persentase penambahan sari jahe merah (Zingiber officinale var. Rubrum). Indonesian Journal of Human Nutrition, 2(1), 38 - 47.

Balitkabi. 2010. Teknologi Produksi Kacang Hijau. Balai Penelitian Tanaman Aneka Kacang dan Umbi, Malang.

Balitkabi. 2012. Deskripsi varietas unggul kacangkacangan dan umbi-umbian. Balai Penelitian Tanaman Kacang-kacangan dan Umbi-umbian. http://balitkabi.litbang.pertanian.go.id/wpcontent/uploads/2016/09/kacanghijau.pdf, diakses: 27 Juni 2018. 
Bayu, M. S. Y. I., Tantawizal, \& Prayogo, Y. (2015). Tingkat serangan penggerek polong pada genotife kedelai tolerann ulat grayak. Pros. Sem. Nas. Hasil Penelitian Tanaman Aneka Kacang dan Umbi Peran Inovasi Teknologi Aneka Kacang dan Umbi dalam Mendukung Program Kedaulatan Pangan.

BPS (Badan Pusat Statistik). (2017). Produksi kacang hijau. https://www.bps.go.id/site/resultTab. diakses 24 November 2017.

Darmawan, J. \& Baharsjah, J.S. (2010). Dasar-Dasar Fisiologi Tanaman. SITC. Jakarta.

Ekafitri, R. \& Isworo, R. (2014). Pemanfaatan kacang-kacangan sebagai bahan baku sumber protein untuk pangan darurat. Pangan, 23(2), 134-145.

Hare, J.D. \& Elle, E. (2002). Variable impact of diverse insect herbivores on dimorphic Daturawrightii. Ecol., 83, 2711-2720.

Howe, H.F. \& Westly, L.C. (1988). Ecological Relationship of Plants and Animals. Oxford Univ Press.

Indiati, S.W. (2004). Penyaringan dan mekanisme ketahanan kacang hijau MLG-716 terhadap hama Thrips. Jurnal Litbang Pertanian, 23(3), 100106.

Indiati, S. W. (2007). Pengendalian hama penggerek polong pada per tanaman kacang hijau. Jurnal Penelitian dan Informasi Pertanian Agrin, 11 (2), 138-147.

Iswandari, R. (2006). Studi kandungan isoflavon pada kacang hijau (vigna radiata l), tempe kacang hijau, dan bubur kacang hijau. Skripsi. Fakultas Pertanian. Institut Pertanian Bogor, Bogor.

Kalshoven L G E. (1981). Pest of Crop in Indonesia. Ichtiar Baru, Jakarta.

Komah, R. I. (2013). Pengaruh substitusi tepung kacang hijau terhadap tingkat kesukaan kue jongkong. E-Journal Boga, 2(3), 18-24.

Marijuana. (2008). Trichomes. http:// www.trichomes.com/2008/trikoma.html. Diakses 02 November 2018.

Marwoto. 1993. Pengendalian hama kacang hijau. Monograf Balitkabi: 86-96.

Nugraha, A. P. (2013). Kelimpahan hama dan musuh alami pada per tanaman kacang hijau (Vigna radiata 1.). Skripsi. Fakultas Pertanian. Institut Pertanian Bogor, Bogor.

Purwono dan R. Hartono. 2005. Kacang Hijau (teknik budidaya di berbagai kondisi lahan dan musim). Penebar Swadaya, Jakarta.

Rahayu, A. \& Sumpena, U. (2015). Perbandingan hasil produksi beberapa galur tanaman mentimun hibrida (Cucumis sativus L.) dengan varietas hercules dan wulan. Hal: 619-626. Pros. Sem.
Nas. Swasembada Pangan. Hidayat, B.,A. A. Candra, Sarono, Y. Sukarya, dan A. R. Gusta. Politeknik Negeri Lampung, 29 April 2015.

Roslim, D. I., Herman, \& Fiatin, I. (2015). Lethal dose 50 (LD50) of mungbean (Vigna radiata L. Wilczek) cultivar Kampar. Sabrao Journal of Breeding and Genetics, 47(4), 510-516.

Saragih, E. S., \& Pangestiningsih, Y. (2015). Uji Efektifitas Insektisida Biologi terhadap Hama Penggerek Polong (Maruca testulalis Geyer.) (Lepidoptera; Pyralidae) pada Tanaman Kacang Panjang di Lapangan. Jurnal Agroekoteknologi Universitas Sumatera Utara, 3(4), 1468-1477.

Sarwono, J. (2006). Metode Penelitian Kuantitatif dan Kualitatif. Graha Ilmu, Yogyakarta.

Singh, K. K., C. Srinivasrao, \& Ali, M. (2008). Phosphorous and mung bean residue incorporation improve soil fertility and crop productivity in sorghum and mungbean-lentil cropping system. Journal of Plant Nutrition, 31(3), 459-471.

Sitompul, M., \& Guritno, B. (1995). Analisis Pertumbuhan Tanaman. Gadjah Mada University Press, Yogyakarta.

Sodic, M. (2009). Ketahanan Tanaman Terhadap Hama. UPN Press, Yogyakarta.

Souza, B. H. S., Júnior, A.L.B., Janini, J.C., Silva, A.G., Rodrigues, N.E.L. (2012). Feeding of Spodoptera eridania (Lepidoptera: Noctuidae) on soybean genotypes. Revista Colombiana de Entomología, 38(2), 215-223.

Surtinah. (2007). Korelasi pertumbuhan organ vegetatif dengan produksi kedelai (Glycine max, (L) Merill). Sem. Nas. Mitigasi Dan Strategi Adaptasi Dampak Perubahan Iklim Di Indonesia.Universitas Lancang Kuning. ISBN: 978-979-3793-70-2.

Talekar, N.S. (1998). Insect pests of mungbean and their control. In: Multilocation testing on mungbean germplasm training course: lecture handout. Nakhon Pathom (TH): Kasetsart University.

Tamang, S., P. Venkatarao, \& G. Chakraborty. (2017). Varietal screening of mungbean cultivars for resistance/tolerance against insect pest under Terai Agro ecological zone of West Bengal. International Journal of Plant Protection, 10(1), 7-13.

Yuliati. (2016). Analisis interaksi genotipe $\mathrm{x}$ lingkungan dan stabilitas galur mutan harapan kacang kijau [Vigna radiata (L.)]. A Scientific Journal for The Applications of Isotopes and Radiation, 12(1), 37-48.

Zaki. (2013). Media Tanam Sebagai Faktor Eksternal yang Mempengaruhi Pertumbuhan Tanaman. Balai Besar Perbenihan dan Proteksi Tanaman Perkebunan 